\title{
EVALUATING SOUTH AFRICA'S VARIOUS ALTERNATIVE FUTURES VIA THE AHP
}

\author{
by \\ Paul Fatti \\ Department of Statistics \\ and \\ Alf Stadler \\ Department of Political Studies \\ University of the Witwatersrand \\ P.O. Wits, Johannesburg 2050, South Africa
}

\section{ABSTRACT}

This paper describes a pilot study in which Saaty's Analytic Hierarchy Process (AHP) is used to try and gain some insight into what form of society will prevail in South Africa in the forseeable future. The problem is structured in a hierarchy in which the actors, or power-groups, are at the top and the alternative future scenarios are at the bottom. Panelists are used to establish the relative influences of the different actors as well as the preferences which each of the actors have for the different scenarios, by means of two-way matrices of paired comparisons. The results of the excercise are discussed, as is the use of this approach in a more serious attempt to forecast South Africa's future political, social and economic system.

\section{INTRODUCTION}

Over the past few years, possibly more so than during any other comparable period since World War 2, South Africa's political, social and economic system has come under great pressure for change, both from within and from outside its borders (Stadler [1], Frankel et al.[2], Lodge [3]). The present system is becoming even less tenable than it has been in the past, as the increasingly violent opposition to it, and 
the corresponding repressive measures adopted by the authorities, including the imposition of states of emergency and the restriction of many black opposition groups, clearly attests.

The outside world, in particular the United States of America, have reacted to the situation by applying increased pressure on the South African Government to change its policies, for example by imposing limited trade sanctions and encouraging disinvestment from the country.

The reaction from within the dominant political order to these pressures has been varied, ranging from a stated commitment by the government to a programme of reform and to the abolition of apartheid, to the emergence of a strong conservative movement opposed to any form of liberalisation of the system and, in fact, pressing towards a greater amount of separation between the different races of the country. One of the aspects of this reform programme has been to include South Africa's so-called Coloured and Indian populations into the governmental process by creating a tricameral parliament in which the Whites, Coloureds and Indians occupy the different chambers, and decide on matters of concern to their respective groups. However, the exclusion of Blacks from representation in parliament, the in-built hegemony of the White chamber over the other two, but mainly the fact that it is seen as merely an extension of the apartheid system, has given it littlecredibility amongst the majority of South Africans and the outside world.

In the meantime, the black population, denied the right to participate in the central government and frustrated by the Government's slow pace of reform, are becoming more. impatient for change. Represented by students, the unions, the UDF (United Democratic Front), some of the non-independent homeland leaders and other pressure groups, they are increasing the pressure by means such as strikes, stayaways and boycotts. A slowdown in the economy over the past few years and the concomitant rise in unemployment have also fuelled the fires of unrest. Other groups, such as the ANC (African National Congress, which is banned in South Africa), committed to taking over power from the present government, have increased the use of violent means to achieve their ends. The inevitable response from the government is to crush these forms of dissent, resulting in an increase in repression and the reimposition of the State of Emergency. The smouldering war which has been carrying on between the South African Defence Force and SWAPO (the South West African Peoples Organisation) along the border of Namibia and Angola over the past decade, 
and the sporadic incidences of hostility between South Africa and its neighbours, have also resulted in increased uncertainty and militarisation.

Under these circumstances the man in the street, be he black or white, is concerned about the future, and about what form of society will prevail in South Africa then. The aim of this paper is to try and gain some insight into that question by means of Saaty's Analytic Hierarchy Process (AHP).

\section{THE ANALYTIC HIERARCHY PROCESS APPLIED TO THE SOUTH AFRICAN SCENE}

The AHP is an approach towards decision making, prioritization or eliciting of preferences in complex situations, where several criteria may pertain or a number of pressure groups or 'actors' may be important. Developed by T.L. Saaty during the 'seventies', it has been applied to a wide range of decision problems, ranging from National planning to conflict resolution. Good descriptions of the approach appear in many texts (Saaty [4],[5]), and it has been implemented on a user-friendly software package for microcomputers (Forman and Saaty [6]).

The two fundamental steps of the AHP are, firstly, the structuring of the problem into a hierarchy, with the criteria or actors towards the top and the alternatives at the bottom and, secondly, the prioritization of the elements at the same level in the hierarchy by means of pairwise comparisons. Priorities which best fit the reciprocal matrix of pairwise comparisons are estimated by means of an eigen-analysis which, in addition to the priorities, also provides a measure of the internal consistency of the set of pairwise comparisons. The priorities of the elements in the upper part of the hierarchy are used to weight the priorities of those elements inmediately below them, in a sequential averaging process which eventually yields the weighted average of the priorities of the alternatives at the bottom of the hierarchy.

In the present context, where we are concerned with investigating various future scenarios for South Africa, the different actors, or power-groups, and their relative influences on the future directions of the country, are of prime importance. They therefore appear at the top of the hierarchy, with their different subdivisions immediately below. At the bottom of thehierarchy appear the various future scenarios, related in turn to each of the parties immediately above them. The relative importances of the different actors are first established by the pairwise comparisons 
method, and thereafter preferences for the various scenarios are similarly determined, separately for each of the actors. Overall preferences for the scenarios are then calculated by weighting the individual preferences through the hierarchy, using the relative importances of the different actors as weights.

Saaty (5, pp129-137) describes how such overall preferences for individual scenarios may be used to construct a composite scenario, expressed in terms of the amount of change from the status quo which is expected in each of a few key variables which characterise a society. In the South African context the following were considered to be key variables:

Economic Control, Racial Integration and Political Freedom.

\section{THE ACTORS}

At the overall, most generalised level, there are four main power groups which have influence on the economic, social and political future of South Africa. They are the outside world, the South African Whites, Indians and Coloureds, and Blacks.

Although there are many outside countries and power groups which, for economic or political reasons, apply pressure to influence the course of events in South Africa, the most important parties are:

The United States of America,

Europe, including Britain,

The 'Frontline States', and

The external wing of the ANC.

The USA is important, not only because of its economic muscle, but also because it epitomises the capitalist, western democratic system, to which the South African Government purports to subscribe. Over the past few years the USA has applied various forms of pressure, both political and economic, in an attempt to persuade South Africa to move away from apartheid towards a more democratic form of government. The most recent activity on this front is the disinvestment campaign, as a result of which a number of large American firms have severed their ties with South Africa.

Britain and Europe both have strong historical and cultural links with South Africa, which are probably as important as their economic ties in influencing the course of events in this country. 
The so-called Frontline States, namely Angola, Zambia, Botswana, Zimbabwe and Mocambique are South Africa's neighbours to the North. The South African Government often accuses them of harbouring terrorist infiltrators, and they have therefore borne the brunt of retaliatory raids conducted against them by the South African security forces. Despite this, and the great political differences between these countries and South Africa, their economies are nevertheless heavily dependent on this country.

The external wing of the ANC, which conducts its underground military campaign against South Africa from a base in Lusaka, and publicises its cause from a number of offices around the world, is a force towards revolutionary change in the country.

Among the South African Whites, the following power groups would appear to be important:

The Herstigte Nasionale Party,

The Conservative Party,

The right-wing of the ruling National Party,

The left-wing of the National Party, and

The PFP and Liberal wing.

The Herstigte Nasionale Party (HNP) is an extreme right-wing party which promotes the cause of the Afrikaner alone and espouses a return to old-style apartheid, including a partition of the country into separate areas for the different race groups, including the Whites.

The policies of the Conservative Party, which is now the official opposition party in the White parliament, are similar to those of the HNP but it tries to appeal to a broader spectrum of the South African white population. The Afrikaner Weerstandsbeweging is a far-right extra-parliamentary organisation which, for tactical reasons, supports the Conservative Party. Because its precise policy is unclear, it has not been explicitly included as an actor in this paper.

Both the above two parties are vehemently opposed to the reform programme of the National Party.

The-National Party is the one in power at the moment, and its right-wing represents the ruling philosophy of the party. Basically, this philosophy is one of gradual 
change, eliminating the worst aspects of apartheid and incorporating the various racial groups into the decision-making system of the country, without drastic change to the present power

structure within the country. The left-wing is far bolder, and envisages a far more drasticdismantling of the present political and economic structure, with safeguards built in to protect the minority groups (including the Whites). Included in this group are the Independents, who broke away from the Party just before the recent election for Whites. Both wings believe in maintaining law and order by whatever means necessary, including states of emergency and detention without trial.

The PFP (Progressive Federal Party) and Liberal wing (including members of the UDF) represent those white people who believe that apartheid should be dismantled immediately and that all repressive legislation, including the state of emergency be repealed. A future policy for South Africa, which would include safeguards for minority groups (not necessarily on a racial basis) should be worked out at a national convention at which all parties are represented.

While big business concerns undoubtedly constitute an influential power group in the South African political scene, and at present largely fall withing the White power group, they have not been explicitly identified in this study. Although no single policy can be associated with them, they would tend to be conservative on issues such as labour, but liberal on race matters, thus generally straddling the policies of the left-wing of the National Party and the PFP and Liberal Wing.

The South African Coloured and Indian communities enjoy a limited form of political power, but still suffer under many of the restrictions of the apartheid system. For the purpose of the present exercise, each of these parties is divided into:

Those who are pursuing change through the present limited political structures, and

Those (including members of the UDF) who do not want to compromise themselves by working through the present system.

The following power groupings amongst the South African Blacks are considered to be important in determining South Africa's future: 
The Homeland leaders, excluding Buthelezi,

Buthelezi and his Inkatha Party,

The UDF,

The Unions, and

The internal wing of the ANC.

The Homeland leaders are working within the present system of separate development, in which tribal areas have been accorded a limited form of self-determination. A number of these leaders have accepted independence for their areas (such as the Transkei and Ciskei), but this has not been recognised by the international community.

Chief Buthelezi, alone among the Homeland leaders, has remained active within the central South African political scene. An outspoken critic of the government, he has launched a number of multi-party political initiatives (such as the Kwa-Natal Indaba) aimed at developing new political structures for Kwazulu and Natal, as well as for the country as a whole.

The United Democratic Front (UDF) is a multi-racial grouping of a large number of parties, devoted to promoting change towards a nonracial political system for South Africa. Although it consists largely of Black groups, it enjoys active support and participation from within the White, Coloured and Indian communities. (Since the excercise described in this paper was carried out, the activities of the UDF have been severely restricted by government decree.)

Ever since the establishment of Black and multi-racial trade unions was legalised in South Africa some years ago, the Unions have exercised considerable influence on Industry and hence on the economy as a whole, and have been instrumental in the removal of apartheid structures from the workplace.

Despite being a banned organisation in South Africa, being the focus of a concerted publicity campaign against it by many of the South African media, and being held responsible for a number of terrorist actions within South Africa, the ANC would appear to enjoy considerable support among Black South Africans, particularly the radical youth. 
Figure 1 below therefore represents the hierarchy of the actors in the South African political scene:

\section{FIGURE 1}

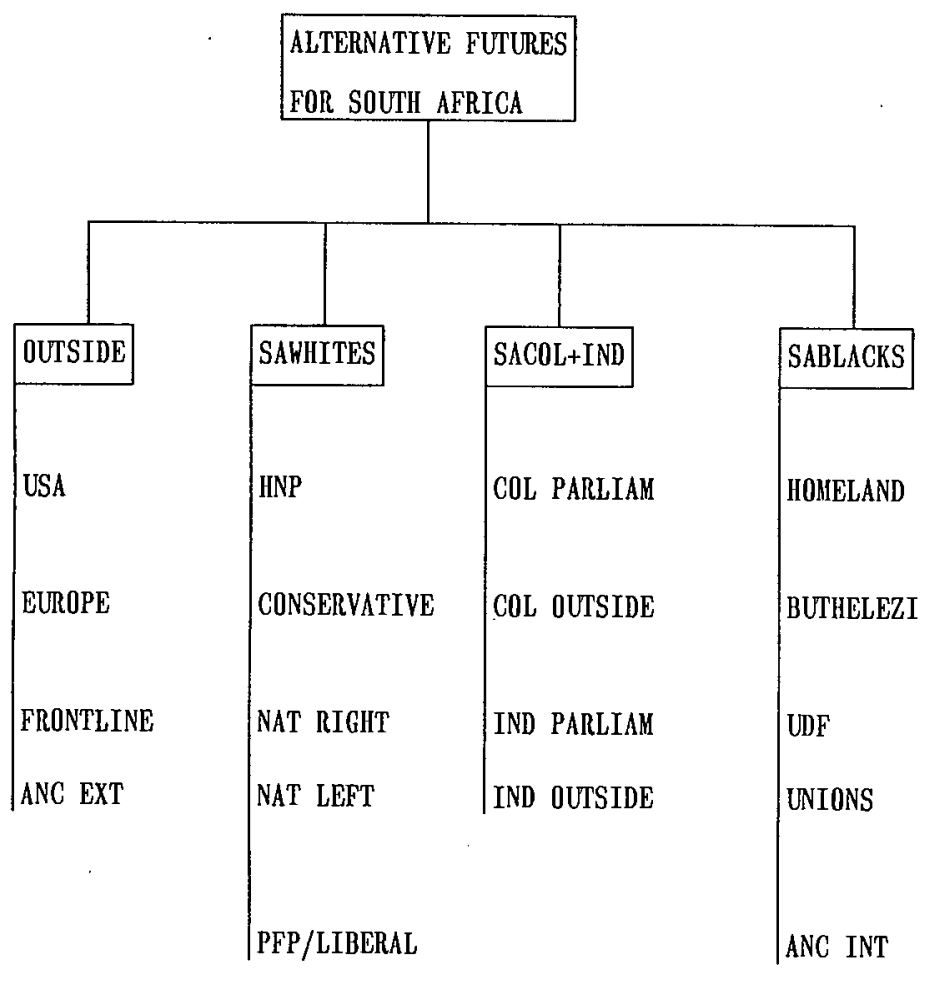

\section{THE FUTURE SCENARIOS}

The following set of future scenarios for South Africa were considered in the study, as they broadly cover the range of forseeable economic, social and political futures that can be envisaged for the following decade or two: 
THE 'SEPARATIST' SCENARIO: This is the system favoured by the white right-wing parties. The economy would be partially market-oriented, partially interventionist, the different races would be separated both socially and geographically, and the political system would at best be some form of restricted democracy, with strong central controls.

THE 'ADAPTED' SCENARIO: This is the system towards which the present government policy seems to be leading the country. It would, broadly speaking, be a market economy; although socially much of the apartheid structure would have been dismantled the concept of 'group identity' would be paramount; and the political system would again be some form of restricted democracy.

THE 'WESTERN' SCENARIO: This is the system generally favoured by the liberal whites as well by the USA and Europe. It would have a market economy, it would be nonracial, and a broadly democratic political system would prevail.

THE 'SOCIALIST' SCENARIO: This is the system which prevails in much of Black Africa. The economy would be more interventionist than market-orientated, it would be nonracial, and a noncompetitive 'African' democracy would prevail (it might, for example, be a one-party state).

THE 'COMMUNIST' SCENARIO: Under this scenario, the economy would be centrally controlled, socially it would be nonracial, and the political system would also be centrally controlled, with very few democratic features.

Although these five scenarios clearly do not cover all the possibilities for South Africa's future, they are sufficiently distinct to enable the various actors to establish meaningful priorities among them. 


\section{ESTABLISHING THE RELATIVE IMPORTANCES OF THE ACTORS}

A small panel of South Africans who are knowlegeable about the country's social and political situation was used to establish the relative importances and priorities, via the method of pairwise comparisons. In addition to the second author, two more academics from the same university, a philosopher and a sociologist, were included in the group. The final member of the panel was an industrialist in a medium-sized engineering firm. Figure 2 below gives the two-way comparison matrix of one of the panelists for the relative importances of the four main power groups in determining South Africa's economic, social and political future:

FIGURE 2

RELATIVE IMPORTANCES OF THE MAIN POWER GROUPS IN DETERMINING SOUTH AFRICA'S FUTURE

\begin{tabular}{r|cccc} 
& OUTSIDE & SA HHITES & SA COL/IND & SA BLACKS \\
\hline OUTSIDE & 1 & $1 / 6$ & $1 / 2$ & 1 \\
SA WHITES & 6 & 1 & 7 & 6 \\
SA COL/IND & 2 & $1 / 7$ & 1 & $1 / 2$ \\
SA BLACKS & 1 & $1 / 6$ & 2 & 1
\end{tabular}

SCALE OF COMPARISON. Row category vs column category:

1 = equally important; $3=$ moderately more important; $5=$ strongly more important; 7 = very strongly more important; $9=$ extremely more important. Even numbers for intermediate importance ratings. Reciprocals if the column category is more important than the row category.

Thus, in the opinion of this panelist, the South African Whites are between strongly and very strongly more important than the outside world in determining South Africa's future, whereas the South African Blacks are considered to be between equally and moderately more important than the South African Coloureds and Indians. 
Applying the eigen-analysis to this pairwise comparison matrix yields the set of relative importances of the four main power groups which best fits the pairwise comparisons. This is given in the first column of Figure 3 , together with the corresponding sets for each of the other panelists. The Inconsistency Ratio, which is also a product of the eigen analysis, provides a measure of inconsistency for the pairwise comparisons matrix. A ratio of zero represents a perfectly consistent set of pairwise comparisons, and one of $10 \%$ or less is generally considered to be satisfactory. A ratio of much more than $10 \%$ represents a set of pairwise judgements which have been made at random.

FIGURE 3

RELATIVE IMPORTANCES OF THE FOUR MAIN POWER GROUPS AS ASSESSED BY EACH OF THE FOUR PANELISTS

\begin{tabular}{r|cccc} 
& $\begin{array}{rlcc}\text { POLITICAL } \\
\text { SCIENTIST }\end{array}$ & PHILOSOPHER & SOCIOLOGIST & INDUSTRIALIST \\
\hline OUTSIDE &, 093 &, 055 &, 065 &, 038 \\
SA HIIITE &, 665 &, 415 &, 415 &, 424 \\
SA COL/IND &, 109 &, 089 &, 070 &, 114 \\
SA BLACK &, 133 &, 441 &, 450 &, 424 \\
\hline INCONSISTENCY & $7,0 \%$ & $8,1 \%$ & $0,5 \%$ & $4,9 \%$ \\
RATIO & & & &
\end{tabular}

Thus the outcome of the political scientist's pairwise judgements is that the Whites hold the absolute majority $(66,5 \%)$ of the power to influence South Africa's future, with the other three parties being far down the line with the Blacks having a slight lead over the other two, and the Outside World having the least influence $(9,3 \%)$. In contrast, the other three panelists' pairwise judgements yielded approximately equal power to the Whites and the Blacks, with the Philosopher and the Sociologist giving the Blacks slightly more weight than the Whites and the Industrialist giving them equal weight. Otherwise the weightings of these three panelists are remarkably 
similar. It is interesting that all four panelists assign the Outside World very little influence over South Africa's future.

The inconsistency ratio for this set of pairwise comparisons varies from $0,5 \%$ to $8,1 \%$ over the four panelists, which is quite satisfactory.

Having established relative importances of the four main power groups, the panelists went on to prioritise the relative importances of the actors within each of them. This involved completing four sets of pairwise comparisons, one for each of the main power groups, and the results of these are presented in Figure 4 for one of the panelists:

\section{FIGURE 4}

RELATIVE IMPORTANCES OF TIE ACTORS UITIIN EACI OF THE FOUR MAIN POUER GROUPS, AS ASSESSED BY TIE POLITICAL SCIENTIST

\section{TUE OUTSIDE HORLD}

THE USA

EUROPE/UK

FRONTLINE STATES

ANC - EXT WING

(INCONSISTENCY RATIO $=9,3 \%$ )

SOUTII AFRICAN COLOUREDS/INDIANS

COLOUREDS-PARLIAMENTARY

COL,OUREDS-OUTSIDE

INDIANS-PARLIAMENTARY

INDIANS-OUTSIDE

,586

,262

, 102

, 050

(INCONSISTENCY RATIO $=9,3 \%$ )
TIE SOUTI AFRICAN UIITTES

$\begin{array}{cc}\text { THE HNP } & , 066 \\ \text { CONSERVATIVE PARTY } & , 148 \\ \text { RIGHT-WING NATIONALISTS } & , 435 \\ \text { LEFT-HING NATIUNALISTS } & , 319 \\ \text { THE PFP/LIBERAL WING } & , 032 \\ \text { (INCONSISTENCY RATIO }=7,3 \% \text { ) } & \end{array}$

TIE SOUTI AFRICAN BLACKS

HOMELAND LEADERS $\quad, 029$

BUTHELEZI/INKATIIA $\quad, 134$

THE UDF $\quad, 176$

THE UNIONS $\quad, 479$

ANC - INT WING ,182

(INCONSISTENCY RATIO $=9,0 \%$ ) 
Thus, in the viel of this panelist, the United States of America wields almost $59 \%$ of the influence which the outside world has on South Africa's future. Multiplying this numberby the relative importance which this panelist attaches to the Outside World (,093 - see Figure 3), gives an overall Figure of 5,4\% for the influence which the United States of America has in determining South Africa's future. In contrast, this panelist's pairwise judgements yield a figure of $43,5 \%$ for the relative influence of the Right-wing of the National Party among the South African Whites which, given the high rating of $66,5 \%$ which the panelist assigns to this power group, gives this wing the highest overall influence of $28,9 \%$ among the individual actors. The most influential Black actor turns out to be the Unions, at $47,9 \%$ of this power group, which gives it an overall influence of $6,4 \%$ in view of the fact that the South African Blacks are judged by this panelist to have $13,3 \%$ of the overall influence. Once again, this panelist shows an acceptably low level of inconsistency in his pairwise judgements. The other panelists also performed judgements on all the individual actors, the results of which are available on request.

\section{PRIORITIES OF THE SCENARIOS AND A COMPOSITE SCENARIO}

Having established the relative importances of all the actors in this simplified political scenario of South Africa, we can now proceed to determine the priorities which each of them attach to the various alternative futures envisaged in this study. This exercise involved the panelists completing a total of 18 pairwise comparison matrices, each of them involving ten pairwise comparisons between the five alternative futures. The resulting sets of priorities are presented in Figure 5.

FIGURE 5

RELATIVE PRIORTTIES OF THE FIVE FUTURE SCENARIOS FOR SOUTH AFRICA FROM THE VIEWPOINT OF EACH OF THE ACTORS, AS ASSESSED BY THE POLITICAL SCIENTIST

\subsection{THE OUTSIDE KORLD}

$\begin{array}{lllll}\text { SCENARIO } & \text { USA } & \text { EUROPE } & \text { FRONTLINE } & \text { ANCEXT } \\ \text { SEPARATE } & , 096 & , 101 & , 030 & , 052 \\ \text { ADAPTED } & , 207 & , 169 & , 047 & , 052 \\ \text { WESTERN } & , 630 & , 645 & , 203 & , 169 \\ \text { SOCIALIST } & , 035 & , 058 & , 502 & , 438 \\ \text { COMMUNIST } & , 032 & , 027 & , 218 & , 289\end{array}$




\subsection{THE SOUTH AFRICAN UHITES}

SCENARIO HNP

SEPARATE , 558

ADAPTED $\quad, 280$

WESTERN ,094

SOCIALIST $\quad, 037$

COMMUNIST $\quad, 031$

\section{CONSERVATIVE}

, 525

, 292

, 117

, 034

, 032

NAT.
, 305
, 474
, 156
, 037
, 027

NAT.LEFT

, 161

, 351

, 424

, 033

, 031
PFP/LIB

.166

, 208

, 550

, 039

, 037

\subsection{THE SOUTH AFRICAN COLOUREDS AND INDIANS}

SCENARIO COI-PARLM

SEPARATE $\quad, 059$

ADAPTED $\quad, 162$

HESTERN ,618

SOCIALIST , 103

COMMUNIST $\quad, 059$
COL-NONPARLM

, 032

, 063

, 527

,236

, 142
IND-PARLM COL-NONPARLM

$, 057 \quad, 037$

,169 ,054

,618 ,549

$, 097 \quad, 242$

,058 , ,117

\subsection{THE SOUTI AFRICAN BLACKS}

\begin{tabular}{llllll} 
SCENARIO & HOMELAND & BUIHELEZI & UDF & UNIONS & ANCINT \\
SEPARATE &, 293 &, 130 & .032 &, 032 &, 035 \\
ADAPTED &, 485 &, 221 &, 049 &, 047 &, 046 \\
WESTERN &, 157 &, 558 &, 116 &, 157 &, 186 \\
SOCIALIST &, 038 &, 046 &, 512 &, 559 &, 497 \\
COMMINIST &, 027 &, 045 &, 291 &, 205 &, 237 \\
\hline
\end{tabular}

Hardly surprisingly, both the United States of America and Europe favour the 'Western' scenario, whereas the Frontline States and the External Wing of the ANC favour the 'Socialist' Scenario. None of the actors from the outside world like the 'Separatist' scenario, whereas the latter two, in the opinion of this panelist, have some leanings towards the 'Communist' scenario. In contrast, while two of the actors among the South African Whites favour the 'Separatist' scenario, and none of them like either the 'Socialist' orthe'Communist' scenarios. The right-wing of the National Party are considered to favour the 'Adapted' scenario, whereas the left-wing of this party, as well as the PFP/Liberal wing, favour the 'Western' scenario. 
Whereas all four actors from the Coloured and Indian communities favour the 'Western' scenario, those which are operating through the present limited political structures show a slightly greater inclination towards the 'Adapted' scenario and a lower preference for the 'Socialist' scenario than those who refuse to work through the present system. Broadly speaking, the Indian and Coloured actors show very similar preferences. The different actors among the South African Blacks show the greatest range of preferences between the five scenarios. The Homeland leaders show a very similar pattern to the right-wing of the National Party, favouring the 'Adapted' scenario and having the 'Separatist' scenario as their next preference, while the UDF, the Unions and the Internal Wing of the ANC all favour the 'Socialist' scenario, with the 'Communist' scenario as their second choice. Chief Buthelezi and his Inkatha party have a very similar profile to that of the PFP/Liberal wing of the South African Whites, favouring the 'Western' scenario.

The first column of Figure 6 shows the overall preferences for the five scenarios as seen by the political scientist, which have been obtained by combining the preferences of all the actors using the weights which were determined earlier.

\section{FIGURE 6}

FINAL PREFERENCES FOR THE FIVE SCENARIOS RESULTING FROM THE JUDGEMENTS OF EACH OF THE THREE PANELISTS

\begin{tabular}{l|ccc} 
& $\begin{array}{l}\text { POLITICAL } \\
\text { SCIENTIST }\end{array}$ & SOCIOLOGIST & INDUSTRIALIST \\
\hline SEPARATE &, 223 &, 204 &, 165 \\
ADAPTED &, 299 &, 201 &, 314 \\
WESTERN &, 309 &, 257 &, 178 \\
SOCIALIST &, 109 &, 241 &, 168 \\
COMMUNIST &, 060 &, 097 &, 175
\end{tabular}


Thus the overall picture emerging from the all the pairwise judgements of the political scientist is that the most preferred future for South Africa over the next decade or two is the 'Western' scenario, with the 'Adapted' scenario close behind and the 'Separatist' scenario next. Neither the 'Socialist' nor the 'Communist' scenarios feature highly in the list of preferences.

The overall preferences coming out of the same exercise conducted by two of the other panelists are displayed in the remaining columns of Figure 6 . (The responses of the philosopher were unfortunately incomplete, and so overall preferences could not be computed from them) The 'Western' scenario also features top in the profile of the sociologist, but now the 'Socialist' scenario comes a close second. The 'Separatist'and'Adapted' scenarios are next, with approximately the same preferences, and again the 'Communist' scenario comes low down in the scale. The picture emerging from the judgements of the industrialist is somewhat different. Here the 'Adapted' scenario receives the highest preference, with the other four scenarios being roughly equally preferred. In particular, the 'Communist' scenario receives a higher preference score in this profile than in those of the other panelists.

In order to construct a composite scenario from the set of overall preferences of any of the panelists, the following technique, described by Saaty (5), was used.

Three key variables which, in the authors' opinion, characterise the South African society, namely Economic Control, Racial Integration and Political Freedom, were each assigned a scale of -8 to +8 , where the endpoints of the scale represent the opposite extremes of the variable and zero the status quo in South Africa at present. Thus, for example, in Economic Control, -8 represents a totally interventionist economy, while +8 represents a totally free market.

Figure 7 below gives the values which, in the authors' opinion, best represent each of the five scenarios on each of the three key variables, together with the extreme points on each of their scales. 


\section{FIGURE 7}

\section{VALUES OF EACH OF THE FIVE SCENARIOS ON EACH OF THE THREE KEY VARIABLES}

$\begin{array}{lll}\text { Economic Control } & \text { Racial Integration } & \text { Political Freedom } \\ \text { Interventionist }-8 & \text { Races Separated }-8 & \text { Central Control }-8 \\ \text { Communist }-7 & \text { Separate }-6 & \text { Communist }-5 \\ \text { Socialist }-5 & \text { Adapted }+1 & \text { Separate }-4 \\ \text { Separate }-3 & \text { Western }+5 & \text { Socialist }-3 \\ \text { Adapted }+3 & \text { Socialist }+6 & \text { Adapted }-2 \\ \text { Western }+5 & \text { Communist }+6 & \text { Western }+5 \\ \text { Free Market }+8 & \text { Integrated }+8 & \text { Democratic }+8\end{array}$

A composite scenario is now constructed by weighting the value of each scenario on each of the three key variables by the priority of that scenario, and summing over all five scenarios, separately for each key variable. The results of this exercise are presented in Figure 8, separately for each of the three panelists.

\section{FIGURE 8}

COMPOSITE SCENARIOS FOR EACH OF THE PANELISTS

\begin{tabular}{lccc} 
& POLITICAL & & \\
& SCIENTIST & SOCI0LOGIST & INDUSTRIALIST \\
\hline Economic Control & 0,81 & $-0,61$ & $-0,73$ \\
Racial Integration & 1,52 & 2,29 & 2,27 \\
Political Freedom & $-0,57$ & $-1,14$ & $-1,78$ \\
\hline
\end{tabular}

Despite the somewhat different sets of overall preferences emanating from the judgements of the three panelists, their composite scenarios turn out to be fairly similar. Taking a rough average, the following picture emerges for South Africa in the next ten to twenty years, relative to today's situation: the economy will have roughly the same form as today, society will be appreciably more integrated but political freedom will be somewhat more restricted. 


\section{CONCLUSIONS}

The aim of this paper has been to use Saaty's Analytic Hierarchy process to try and gain some insight into what form of society will prevail in South Africa in the forseeable future, once the present forces for change have had time to exert their influence on the economic, social and political scene. Clearly, the most that the present exercise could hope to achieve is to test the usefulness of structuring the problem in a hierarchy and of using themethod of pairwise comparisons to elicit judgements on the relative influences and preferences within this structure. However, it is also hoped that the results which have emerged from the exercise will provide some useful insights, despite the fact that in choosing the panel, no attempt was made to make it representative of South African society, or even to cover the range of opinions present in the society. (Whether the panel should, in fact, be representative, is a moot point.)

While none of the respondents had any background on the AHP, they were all able to use it effectively after having had a brief explanation of the techniques and having the hierarchy presented to them. In fact, although they did not have much understanding of the underlying theory of the AHP, they nevertheless found it an appealing approach towards the problem, and had little difficulty in using it.

If this approach were to be used in a serious attempt to gain some insight into South Africa's political future, then the choice of panelists to complete the pairwise comparisons matrices from which the relative importances of the actors and the preferences of each of the actors are computed, is of paramount importance. The people whose judgements should ideally be used to establish the preferences are representatives of the actors themselves, even though this may in some cases be difficult to achieve. The task of establishing the relative importances of the various power groups, and of the individual actors within them, should most probably be assigned to a panel of experts in political science and strategic studies, possibly using a Delphi-type approach aimed at achieving a measure of consensus on each of the pairwise comparisons. The first author has applied this approach with considerable success in the field of Research Planning (Fatti [7]).In the present pilot excercise it was felt to be more instructive (and practically achieveable) to have each panelist complete all the required comparison matrices separately and then to compare the outcomes of these separate analyses. 
An important question to ask is what do the final preferences for the various scenarios really mean, and how do they relate to the scenario which actually materialises in the next ten to twenty years? If the following assumptions hold:

(1) That economic,political and social structures are shaped by aggregate forces,

(2) That the likelihood of any actor affecting the future scenario is proportional to its relative importance, and

(3) That an actor's influence on the probability of occurrence of any particular future scenario is proportional to its preference for that scenario,

then the overall preferences for the various scenarios can be interpreted as probabilities of them actually occurring.

If not, then these preferences can only be interpreted as a set of weighted average popularities taken over the various actors, which do not necessarily have a direct bearing on which scenario actually materializes. For the former interpretation to be valid it would be necessary that the change process be one of negotiation or bargaining, rather than one of open conflict or revolution in which the winner takes all. It would, in fact, be an interesting exercise to use the AHP to investigate the possible ways in which the actual change process could take place.

Combining a panelist's set of preferences for the individual scenarios into a single, composite scenario is a useful way of summarising these preferences, but depends crucially on the values of the key variables assigned to each of the scenarios. Clearly, a more thorough analysis than that undertaken by the authors would be required to ensure that these values are realislic. More fundamentally, this procedure assumes that the dominant parties under each scenario will all contribute towards the realization of the final scenario which eventually emerges, rather than it being determined on the basis of "the wirner takes all".

Coming finally to the results of the analyses performed by the different panelists, the first point of interest is the relative importances which they assign to the four main power groups, as displayed in Figure 3. While three of the four panelists are remarkably similar in terms of the weights which they attach to the four power groups, and in particular the fact that they all give the South African Whites and Blacks equal importances, the political scientist stands out from the rest, particularly 
in terms of the relatively high weight which he attaches to the South African whites compared to that of the South African Blacks. A possible explanation for this phenomenon is that the political scientist, being more familiar with the realities of power within the political scene, sees less movement away from the status quo in the next decade or two than do the other panelists.

A difference in the perceptions of the timescale among the panelists may also be an explanation.

Regarding the sets of overall preferences which have emerged from the judgements of the different panelists, it is interesting to note that the 'Western' scenario is the most preferred in two of the three sets, while the 'Adapted' scenario comes first in the third set and comes second in one of the others. Broadly speaking, the two 'right-wing' scenarios score more highly than the two 'left-wing' scenarios, with the extreme right-wing 'Separatist' scenario coming out with a non-negligible score ranging from 0,165 to 0,223 . If these preference scores are interpreted as probabilities, these scores would explain the South African government's present preoccupation with what it sees as the right-wing threat.

The composite scenario which finally emerges at the end of the process is possibly not unexpected. Indeed, the competing forces of private enterprise and trade unionism both seem to be sufficiently powerful to resist any great changes taking place from the current economic system. The slow movement away from Apartheid now seems unstoppable, despite the many setbacks along the way and the protestations from the far right. On the other hand, the recent reimposition of the State of Emergency, the continued pressure being applied on political protest and on the media, as well as the increasing executive power being assumed by the State President, all suggest that South Africa is moving away from democracy. Thus, despite the fact that Blacks will almost certainly be gaining increasing political representation at all levels of government, their power (and that of the other actors) to influence the course of events will be somewhat limited.

\section{ACKNOWLEGEMENTS}

We would like to thank Belinda Bozzoli, Vincent Mphai and Andries Wessels for assisting us in our research. 


\section{REFERENCES}

[1] A. Stadler, The Political Economy of Modern South Africa, Croom Helm, London (1987).

[2] P.F. Frankel, N.J. Pines and M. Swilling (eds), State, Resistance and Change in South Africa, Croom Helm, London (1987).

[3] T. Lodge, Black Politics in South Africa since 1945, Longmans, London (1983).

[4] T.L. Saaty, The Analytic Hierarchy Process, McGraw-Hill, New York, (1980).

[5] T.L. Saaty, Decision Making for Leaders, University of Pittsburgh, PA, (1986).

[6] E.I. Forman and T.L. Saaty, Expert Choice, Decision Support Software, VA. (1986).

[7] L.P. Fatti, Identification and Prioritization in Research Planning, Paper presented at the TIMS/ORSA Joint National Meeting, Florida Beach (1986). 